\title{
Program Announcement
}

National Cancer Institute

\section{Source}

National Cancer Institute. Program Announcement. NCI Thesaurus. Code C18233.

A formal statement that describes and gives notice to the grantee community of the existence of an $\mathrm{NIH}$-wide or individual Institute/Center extramural research activity/interest or announces the initiation of a new or modified activity/interest or mechanism of support and invites applications for grant or cooperative agreement support. (from The $\mathrm{NCl}$ Grants Process: Glossary) 